\title{
AGE AND SYMPTOMS OF PRIMARY MANIFESTATIONS OF MULTIPLE SCLEROSIS IN VOLYN REGION (UKRAINE)
}

\author{
N.V. Bobryk ${ }^{1}$, *O.D. Shulga ${ }^{1}$, L.I. Sokolova ${ }^{2}$ \\ ${ }^{1}$ Volyn Regional Clinic Hospital, Volyn, Ukraine \\ ${ }^{2}$ National Medical University named after O.O. Bohomolets, Kyiv, Ukraine
}

Approximately 2.3 million patients in the world suffer from multiple sclerosis (MS). $20674 \mathrm{MS}$ patients were registered in 2012 in Ukraine, representing 55.3 cases per 100 thousands of population [4]. In the Volyn region, the prevalence of MS on 01.01.2013 is 101.0 cases per 100 thousand population and is the largest among of the regions [2]. According to the study MSIF (Multiple Sclerosis International Federation) 2013, primary clinical manifestations of MS are sensitive $(40 \%)$, visual $(30 \%)$, motor $(39 \%)$, cognitive $(10 \%)$, pain $(15 \%)$, sexual $(20 \%)$ disorders. About $30 \%$ of patients at the onset of MS experience fatigue, 24\% - balance disorders, $17 \%$ - a violation of urination. These findings are ambiguous, because among the residents of some countries that participated in the registry, problems of dysfunction of pelvic organs and sexual disorders are the topics which hareless discussed than a visual or motor disorders [8].

Many studies have found that age of debut, its clinical symptoms, the presence and duration of complete remission after the first symptoms of the disease are possible predictors of subsequent disease progression and the rate of disability. Typical of most studies is the predominance of onset of the disease between the ages of 20 and 40 years (70\% of all cases) [7]. Only visual (optic neuritis) [9] or sensory disturbances as the initial manifestation of the disease is a sign for favorable further prognosis [6]. Late debut aged over 45 years is characterized by a high index of progression and poor prognosis regarding quick disability that is likely due to the more active neurodegenerative processs in this age group [5]. There are observations that patients with pyramidal or pelvic disorders at onset of the disease are at increased risk of a rapid deterioration in neurological deficit and achievement of secondary progressive stages of MS [6]. Problems regarding the prognostic value of the duration and completeness of remission have been widely discussed in the literature.
Research over the past decades proves the view that long-term remission after the debut of disease should be regarded as a subclinical stage of continuous course of autoimmune process that leads to the disruption of adaptive-compensatory mechanisms due to the lack of adequate immunosuppressive therapy in such patients. As a result, the disease transforms into progressive forms [3]. The rate of relapse in the first year is not considered a predictor of future course of disease. More important for the prognosis are clinical features of relapses, unfavorable sign is the presence of a pyramidal or pelvic disorders[1].

Purpose: to analyze the age and clinical features of debut of MS in the Volyn cohort of patients.

Materials and methods. The Volyn registry of patients with MS was established in Volyn regional hospital in 2012. 825 patients were registered in Volyn region as of 01.01.13. In order to study the characteristics of MS in Volyn region, questionnaires were sent to patients that included queries relating to age of onset of the disease, age of diagnosis, symptoms that were the first manifestations of the disease, the availability of complete remission in early MS, time, expired from debut to the disappearance of complete remissions. The results obtained from 227 respondents, including 153 females and 73 males, mean age $43 \pm 10.6$ years. Data were entered into an electronic database and were processed using computer programs Excel and Statistica 6.0.

Results. The mean age of onset of MS was $29.5 \pm 9.4$ years, the mean age of diagnosis was $33.2 \pm 9.5$ years.

It was offered patients to choose among listed symptoms those which they experienced at the onset of disease. The frequency of occurrence of certain disorders in absolute numbers and percentage of total respondents indicated in the table. 1

* e-mail: shulgaolga@ukr.net 
Frequency of occurrence of symptoms at the onset of MS, and mean age of patients who indicated the presence of symptom

\begin{tabular}{|c|c|c|c|c|c|c|}
\hline \multirow[t]{2}{*}{ № } & \multirow[b]{2}{*}{ Symptoms } & \multicolumn{2}{|l|}{ YES } & \multicolumn{2}{|l|}{$\mathrm{NO}$} & \multirow{2}{*}{$\begin{array}{l}\text { Mean age of } \\
\text { patients }\end{array}$} \\
\hline & & Abs. N & $\%$ & Abs N & $\%$ & \\
\hline 1 & Visual loss (optic neuritis) & 98 & 43 & 127 & 56 & $28.8 \pm 9.7$ \\
\hline 2 & Numbing/ tingling & 156 & 68.7 & 68 & 30 & $29.7 \pm 8.9$ \\
\hline 3 & Dizziness, nausea, vomiting & 123 & 54.2 & 100 & 44 & $29.4 \pm 9.8$ \\
\hline 4 & Diplopia & 95 & 41.8 & 130 & 57 & $29.2 \pm 9.9$ \\
\hline 5 & Gait disturbance & 196 & 85 & 29 & 12.8 & $29.6 \pm 9.4$ \\
\hline 6 & Weakness of one or more limbs & 191 & 84.1 & 34 & 15 & $29.9 \pm 9.3$ \\
\hline 7 & Facial asymmetry & 26 & 11.5 & 198 & 87.2 & $28.9 \pm 11.7$ \\
\hline 8 & Urinary and bowel disorders & 107 & 47.1 & 118 & 52 & $30.2 \pm 9.7$ \\
\hline 9 & $\begin{array}{l}\text { Violations of sensitivity (sharp } \\
\text { or dull, temperature, vibration) }\end{array}$ & 85 & 37.4 & 138 & 60.8 & $29 \pm 9.6$ \\
\hline 10 & Speech disorders & 80 & 35.2 & 144 & 63.4 & $30.6 \pm 10.0$ \\
\hline 11 & $\begin{array}{l}\text { Visual disorders (restriction of } \\
\text { visual fields, color perception } \\
\text { disorders) }\end{array}$ & 78 & 34.4 & 146 & 64.3 & $29.3 \pm 9.9$ \\
\hline 12 & Low back, limbs or facial pain & 117 & 51,5 & 108 & 47,6 & $31,0 \pm 9.0$ \\
\hline 13 & $\begin{array}{l}\text { Fatigue, depressionor euphoria, } \\
\text { decrease in mentation }\end{array}$ & 152 & 67 & 73 & 32.2 & $29.2 \pm 9.2$ \\
\hline
\end{tabular}

Thus, the most common symptoms of debut of MS were gait disturbance and weakness of the limbs. Most rarely at the initial stage of disease, patients indicated the presence of facial asymmetry, violations of sensitivity and color perception, restriction of visual fields, speech disorders. The mean age of onset of MS among those who reported about urinary and bowel dysfunction, speech disorders, pain of low back, limbs or face at the debut of disease was higher compared to patients who did not noted these symptoms .

In Table 2 is shown the frequency of occurrence of each of these symptoms in absolute numbers and percentages in groups depending on the age of onset of MS (till 25 years, from 25 years inclusive - till 40 years of age, from 40 years inclusive).

Found that patients with the onset of MS till 25 years more often complained of feeling of constant fatigue, depression or euphoria, decrease in mentation at the initial stage of disease compared to patients with more recent debut of MS. There is a gradual decrease in the percentage of patients who noted these symptoms at the onset of the disease with increasing age of onset of MS. In contrast, patients in whom the disease began after age 40, often pointed to dysfunction of the pelvic organs, disorders of speech, pain in the extremities, back, face. The percentage of patients who report the presence of these disorders in their early disease increases with age debut. In the age group with the onset of MS from 25 to 40 years, respondents more likely than in other groups pointed to the occurrence of numbing sensation or tingling in any part of the body at the early stage of disease.

99 of $227(44 \%)$ of respondents noted remission at the beginning of disease, during which were completely healthy. 36 of 227 patients $(16 \%)$ noted the presence of complete remission and so far, 168 (74\%) indicated the presence of certain signs of MS in a period of remission. The mean duration of remission indicated by patients was 1 year 4 months, minimum remission lasted 1 month, maximum remission lasted 20 years. The mean time from onset of MS to disappearance of complete remission was 5 years \pm 4 years.

Conclusions. This project is the first region wide large-scale MS survey, covering approximately 1/4 of patients, according to our estimates. The results identify the features of age and primary manifestations of MS in Volyn population. The more common occurrence of pelvic dysfunction, 
Table. 2

Primary symptoms of MS depending on age of onset of disease

\begin{tabular}{|c|c|c|c|c|}
\hline & \multirow{2}{*}{ Symptoms } & \multicolumn{3}{|c|}{ Age of onset } \\
\hline & & $\begin{array}{l}<25 \text { years } \\
(\mathrm{n}=70)\end{array}$ & $\begin{array}{c}25-40 \text { years } \\
(\mathrm{n}=112)\end{array}$ & $\begin{array}{l}\text { From } 40 \text { years } \\
\text { inclusive }(n=39)\end{array}$ \\
\hline 1 & Visual loss (optic neuritis) & $33(47.1 \%)$ & $48(42.9 \%)$ & $16(41 \%)$ \\
\hline 2 & Numbing/ tingling & $\begin{array}{c}46(65.7 \%)^{1} \\
p=0.0412\end{array}$ & $84(75 \%)^{1}$ & $\begin{array}{c}24(61.5 \%)^{1} \\
p=0.007\end{array}$ \\
\hline 3 & Dizziness, nausea, vomiting & $38(54.3 \%)$ & $61(54.5 \%)$ & $20(51.3 \%)$ \\
\hline 4 & Diplopia & $30(42.9 \%)$ & $48(42.8 \%)$ & $17(43.6 \%)$ \\
\hline 5 & Gait disturbance & $63(90 \%)$ & $94(83.9 \%)$ & $34(87.2 \%)$ \\
\hline 6 & Weakness of one or more limbs & $57(81.4 \%)$ & $98(87.5 \%)$ & $33(84.6 \%)$ \\
\hline 7 & Facial asymmetry & $11(15.7 \%)$ & $8(7.1 \%)$ & $6(15.4 \%)$ \\
\hline 8 & Urinary and bowel disorders & $32(45.7 \%)^{2}$ & $51(45.5 \%)^{2}$ & $22(56.4 \%)^{2}$ \\
\hline 9 & $\begin{array}{l}\text { Violations of sensitivity (sharp } \\
\text { or dull, temperature, vibration) }\end{array}$ & $28(40 \%)$ & $40(35.7 \%)$ & $15(38.5 \%)$ \\
\hline 10 & Speech disorders & $21(30 \%)^{3}$ & $40(35.7 \%)^{3}$ & $\begin{array}{c}17(43.6 \%)^{3} \\
\mathrm{p}=0.0448\end{array}$ \\
\hline 11 & $\begin{array}{l}\text { Visual disorders (restriction of } \\
\text { visual fields, color perception } \\
\text { disorders) }\end{array}$ & $24(34.3 \%)$ & $40(35.7 \%)$ & $13(33.3 \%)$ \\
\hline 12 & Low back, limbs or facial pain & $32(45.7 \%)^{3}$ & $62(55.3 \%)^{3}$ & $\begin{array}{l}23(59 \%)^{3} \\
p=0.0337\end{array}$ \\
\hline 13 & $\begin{array}{l}\text { Fatigue, depression or euphoria, } \\
\text { decrease in mentation }\end{array}$ & $50(71.4 \%)^{3}$ & $77(68.8 \%)^{3}$ & $\begin{array}{c}24(61.5 \%)^{3} \\
\mathrm{p}=0.0334\end{array}$ \\
\hline
\end{tabular}

Notes:

1 - statistically significant differences were reached between the second and the first and the second and the third groups of patients;

2 - statistically significant difference was not reached;

3 - statistically significant difference was reached between the first and the third group of patients.

speech disorders and painful feelings at the onset of disease in patients after 40 agrees with results of other similar investigations. The younger age of

\section{REFERENCES}

1. Костюченко А. В. Принципи клінічного ведення та організації диспансерного нагляду хворих на множинний склероз на регіональному рівні: дис. ... кандидата мед. наук: 14.01.15/ Костюченко Андрій Володимирович. - Вінниця, 2012. - 190с.

2. Показники діяльності ЛПз Волинської області за 2011-2012 pp./[укладачі С. Бондаренко та ін.]. - Луцьк, 2013. - 435c.

3. Порівняльна характеристика даних регіональних регістрів розсіяного склерозу у Східному та Західному регіонах України/ Н.П.Волошина [та ін.] // Международный неврологический журнал. - 2005. - №3. - С.63-64. 4. Розсіяний склероз: глобальні перспективи/ Т.С.Міщенко, О.Д.Шульга, Н.В.Бобрик [та ін.]//Український медичний часопис. - 2014. - №3. - С.84-87.

5. Age at onset determines the occurrence of the progres- debut of MS, as a rule, associates with mild primary clinical manifestations of disease and predicts more favorable course of disease.

sive phase of multiple sclerosis/ B. Stankoff [et al.]// Neurology. - 2007. - Vol.68, № 10. - P.779-781.

6. Course and prognosis in early-onset MS: comparison with adult-onset forms/ I.L. Simon [et al.]// Neurology. 2002. - Vol.59, № 12. - P. 1922-1928.

7. Kobelt G. Access to innovative treatments in multiple sclerosis in Europe. A report prepared for the European federation of pharmaceutical industry associations (EFPIA)/ G/ Kobelt, F. Kasteng. - 2009. - 89p.

8. Multiple Sclerosis International Federation (2013) Atlas of MS 2013: Mapping multiple sclerosis around the world (http://www.msif.org/about-ms/publications-andresources/atlas-of-ms-2013.aspx)

9. Potemkowski A. Optic neuritis as the intial manifestation of multiple sclerosis/ A.Potemkowski//Klin.Oczna. 2000. - Vol. 102, № 2. - P. 95-98. 


\title{
РЕЗЮМЕ
}

\section{ВОЗРАСТ И СИМПТОМЫ ПЕРВЫХ ПРОЯВЛЕНИЙ РАССЕЯННОГО СКЛЕРОЗА НА ВОЛЫНИ (УКРАИНА)}

\author{
Н.В. Бобрик'1, О.П. Шулга', Л.И. Соколова2 \\ 1Вольнсккая областная клиническая больница, Вольнь, Украина; \\ ${ }^{2}$ Национальный медицинский университет имени О.О.Богомольца, Киев, Украина
}

Цель: проанализировать возраст и клинические особенности дебюта РС в Волынской когорте пациентов.

Материалы и методы. Для изучения характеристик РС в Волынской области, больным РС были разосланы анкеты, которые включали вопросы, касающиеся особенностей их болезни. Получены результаты от 227 респондентов (153 женщины и 73 мужчины, средний возраст $43 \pm 10,6$ лет).

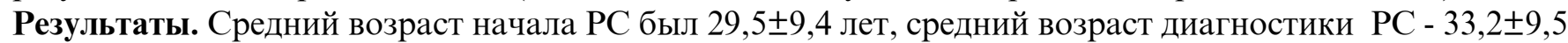
лет. Самыми распространенными симптомами дебюта РС были нарушения походки и слабость в конечностях. Наиболее редко в начальной стадии заболевания пациенты указывали на присутствие асимметрии лица, нарушений чувствительности и восприятия цвета, ограничений полей зрения, нарушений речи. Пациенты с началом РС до 25 лет в начальной стадии заболевания чаще жаловались на чувство постоянной усталости, депрессии или эйфории, снижение мышления по сравнению с пациентами с более поздним дебютом РС. Пациенты, у которых заболевание началось после 40 лет, чаще указывали на нарушения функции тазовых органов, нарушения речи, боли в конечностях, спине, лице. В возрастной группе с наступлением РС от 25 до 40 лет, респонденты чаще, чем в других группах указывали на возникновение ощущения онемения или покалывания в любой части тела на ранней стадии заболевания. Средняя продолжительность ремиссии, указанной пациентами была 1 год 4 месяца, минимальная ремиссия продолжалась 1 месяц, максимальная ремиссия длилась 20 лет. Среднее время от начала РС к исчезновению полных ремиссии составляло 5лет 4 года.

Выводы. Этот проект является первым обще региональным масштабным опросом, охватывающим примерно 1/4 больных РС в Волынской области. Результаты отображают возрастные и клинические особенности РС у пациентов Волынской области (Украина) и согласовываются с результатами других похожих исследований. 


\title{
XÜLASə
}

\section{VOLINDA (UKRAYNA) DAĞINIQ SKLEROZUN İLKINN ĐLAMӘTLəRINNIN YARANMA YAŞI Və SIMPTOMLARI}

\author{
N.V.Bobrik ${ }^{1}$, O.P.Şulqa ${ }^{1}$, L.İ.Sokolova ${ }^{2}$ \\ ${ }^{1}$ Volın rayon klinik xastaxanasi, Volın, Ukrayna; \\ ${ }^{2}$ O.O. Boqomoles adına milli tibb universiteti, Kiyev, Ukrayna
}

\begin{abstract}
Məqsəd: Volın pasiyentləri koqortunda dağınıq skleroz (DS) debütünün yaş və klinik xüsusiyyətlərinin todqiqi.

Material və metodlar. Regionda DS-in xarakteristikasının tədqiqi üçün, bütün xəstələrə anketlər göndərilmişdir. Bu anketlərə onların xəstəliklərinin xüsusiyyətlərini əhatə edən suallar daxil edilmişdir. 227 respondentlərdən (153 qadın və 73 kişi, orta yaş $43 \pm 10,6$ yaş) nəticələr əldə edilmişdir.

Nəticələr. DS-in başlanmasının orta yaş dövrü 29,5 $\pm 9,4$ yaş olmuşdur, DS diaqnozunun qoyulmasının orta yaşı 33,2 $\pm 9,5$ yaş təşkil etmişdir. DS debütünün ən çox yayılmış simptomatikası yerişin pozulması ətraflarda zəiflik olmuşdur. Nadir hallarda pasiyentlər xəstəliyin başlanğıc mərhələsində üzün asimmetriyası, hissiyyat pozulması və rəng qavramasının pozulmasından, görmə sahəsində məhdudiyyətlərdən və nitq pozulmasından şikayətlənmişdirlər. 25 yaşa qədər dövrdə başlanan DS-li xəstələr daha yaşlı dövrdə xəstələnən şəxslərdə müqayisədə daha çox daimi yorğunluq hissi, depressiya və ya eyforiya, təfəkkürün zəifləməsindən şikayət edirdilər. DS 40 yaşından sonra başlanan xəstələr çox vaxt çanaq orqanların funksiya pozulmasından, nitq pozulmalarından, ətraflarda, beldə və üzdə ağrılardan şkayətlənirdilər. 25-40 yaş dövründə DS ilə xəstələnən pasiyentlər xəstəliyin daha erkən mərhələlərində digərlərindən daha çox bədənin hər hansı hissəsində keyləşmə və ya iynə batma hissindən şikayətlənirdilər. Pasiyentlər tərəfindən gğstərilən remissiyanın orta davam etmə müddəti 1il 4 ay, minimal remissiya 1 ay, maksimal remissiya 20 il sürmüşdür. DS-in başlanmasından tam remissiyaya qədərolan müddət 5 yaş \pm 4 yaş olmuşdur.

Müzakirə. Bu proyekt ilk ümumregional miqyaslı sorğudur, Volın rayonunun DS-li xəstələrinin təqribən 1/4ni əhatə etmişdir. Nəticələr Volın (Ukrayna) rayonunun əhalisi arasında DS-in yaş və klinik xüsusiyyətlərini əks etdirir və digər oxşar tədqiqatların nəticələri ilə razılaşdırılır.
\end{abstract}

Redaksiyaya daxil olub: 01.07.2014

Çapa tövsiyə olunub: 26.07.2014

Rəyçi: t.ü.f.d., dosent, Z.M.Sadıxova 